\title{
PHOTOMAPPING: Mengasah Kreativitas Siswa dengan Photografi
}

\author{
Ni Wayan Ekayanti ${ }^{1 *}$, Ida Bagus Ari Arjaya ${ }^{1}$, Ni Ketut Anggraini1 \\ 1. PSP Biologi, FKIP, Universitas Mahasaraswati Denpasar, Denpasar, Indonesia \\ email: ekayanti@unmas.ac.id
}

\begin{abstract}
Abstrak
Tujuan dari penelitian ini adalah untuk mengasah kreativitas siswa dalam merancang photomapping dengan photografi melalui penerapan model pembelajaran Projek Based Learning. Jenis penelitian yang digunakan dalam penelitian ini adalah Quasi-Eksperimental Design dengan rancangan Post-Test Only. Penelitian ini dilaksanakan dari bulan April - Mei 2019, di SMA Negeri 2 Denpasar. Sampel dalam penelitian ini adalah kelas X IPA 5 dan X IPA 9. Data yang dikumpulkan dalam penelitian ini berupa data kuantitatif dengan menggunakan rubrik kreativitas siswa dalam hasilkan photomapping. Data dianalisis menggunakan uji Mann Whitney U test. Hasil dari penelitian ini menunjukkan bahwa kegiatan photografi dengan model pembelajaran Project Based Learning berpengaruh terhadap kreativitas siswa dalam merancang photomapping. Terbukti bahwa terdapat perbedaan yang nyata antara kelas kontrol dan kelas eksperimen yaitu pada kreativitas merancang photomapping $(\mathrm{z}=-3,218, \mathrm{p}=0,001)$ Sehingga dapat disimpulkan bahwa penerapan photografi dengan model $\mathrm{PjBL}$ dapat mengasah kreativitas siswa dalam merancang photomapping.
\end{abstract}

Kata Kunci: Kreativitas, Photografi, Photomapping, Projec Based Learning.

\section{PENDAHULUAN}

Terdapat tuntutan dalam pembelajar kurikulum 2013 menghendaki suatu proses pendidikan yang memberikan kesempatan bagi siswa agar dapat mengembangkan segala potensi yang dimilikinya. Potensi yang terkait dengan aspek sikap (afektif), pengetahuan (kognitif), dan keterampilan (psikomotor). Pembelajaran kurikulum 2013 menghendaki pembelajaran yang mengarah pada pemberdayaan semua potensi siswa sehingga menjadi manusia yang kompetensi dalam kehidupan salah satunya adalah kreativitas.

Dari hasil observasi yang telah dilakukan, ditemukan bahwa siswa di SMA N 2 Denpasar khususnya dalam pembelajaran biologi kurang difasilitasi aspek psikomotoriknya, terutama pada kreativitas siswa, karena kurangnya pengetahuan siswa tentang media pembelajaran yang menarik, dan inovatif. Selain itu, siswa belum pernah menghasilkan sebuah projek berupa media pembelajaran biologi untuk menujang kreativitasnya. Sehingga kurangnya pengetahuan menyebabkan siswa menjadi kebingungan saat diajak merancang media pembelajaran, untuk mengatasi hal tersebut perlu adanya sebuah model dengan media pembelajaran yang tepat untuk menunjang potensi kreativitas siswa dalam merancang media pembelajaran yang menarik, dan inovatif. Photografi adalah proses atau metode menghasilkan gambar atau foto dari suatu objek. Photografi menjadi trend beberapa tahun ini karena dengan kemajuan teknologi, setiap siswa memiliki kamera pada poselnya.

Kamera adalah benda yang selalu ada dalam aktivitas siswa. Fakta inilah yang menjadi basis bahwa sangat mungkin merancang suatu media inovatif yang mampu mengasah kreativitas siswa, yang kemudian dapat digunakan sebagai media pembelajaran. Projek Based Learning adalah model pembelajaran yang menggunakan proyek/kegiatan sebagai media. 
Siswa melakukan eksplorasi, penilaian, interpretasi, sintesis, dan informasi untuk menghasilkan berbagai bentuk hasil belajar (Ainamulyana, 2018). Dengan adanya peranjangan projek tentu saja dapat memunculkan kreativitas siswa. Tujuan dari penelitian ini adalah untuk mengasah kreativitas siswa dalam merancang photomapping dengan photografi melalui penerapan model pembelajaran Projek Based Learning.

\section{Metode}

Jenis penelitian yang digunakan dalam penelitian ini adalah Quasi-Eksperimental Design dengan rancangan penelitian perbandingan kelompok berhubungan (Post-test Only). Penelitian ini dilaksanakan dari bulan April - Mei 2019, di SMA Negeri 2 Denpasar. Populasi dalam penelitian ini adalah seluruh kelas X IPA SMA Negeri 2 Denpasar, dengan sampel kelas X IPA 5 sebagai kelas kontrol, dan kelas X IPA 9 sebagai kelas eksperimen. Variabel bebas pada penelitian ini adalah model pembelajaran projek based learning (PJBL) dan variable terikat dalam penelitian adalah kreativitas siswa dalam menghasilkan photomapping. Data yang dikumpulkan dalam penelitian ini berupa data kuantitatif dengan menggunakan rubrik kreativitas siswa dalam menghasilkan photomapping. Data yang didapatkan kemudian dianalisis menggunakan uji Mann Whitney U test.

\section{Hasil}

Berdasarkan penilaian terdapat perbedaan jumlah rata - rata dari keempat aspek kreativitas siswa dalam menghasilkan photomapping antara kelas kontrol dan kelas eksperimen. Kelas eksperimen memperoleh rata - rata skor lebih tinggi $(10,5)$ dibandingkan dengan kelas kontrol $(9,3)$. Perbandingan distribusi frekuensi siswa kelas kontrol dan kelas eksperimen disajikan pada Tabel 1

Tabel 1 Perbandingan Distribusi Frekuensi Kreativitas Antara Kelas Kontrol Dengan Kelas Eksperimen

\begin{tabular}{ccccccc}
\hline No & Kategori & Interval & $\begin{array}{c}\text { Kontrol } \\
(\mathrm{N}=30)\end{array}$ & $(\%)$ & $\begin{array}{c}\text { Eksperimen } \\
(\mathrm{N}=30)\end{array}$ & $(\%)$ \\
& & $\mathrm{F}$ & & $\mathrm{F}$ & \\
\hline 1 & Kurang Baik & $4-6$ & 1 & 3,3 & 0 & 0,0 \\
2 & Cukup & $7-9$ & 14 & 46,7 & 4 & 13,3 \\
3 & Sangat Baik & $10-12$ & 15 & 50,0 & 26 & 86,7 \\
\hline
\end{tabular}

Pada Tabel 1 terdapat perbedaan distribusi frekuensi antara kelas kontrol dengan kelas eksperimen. Frekuensi skor kreativitas siswa dalam menghasilkan photomapping pada kelas kontrol (15) berada pada kategori sangat baik, (14) berada pada kategori cukup, dan kategori kurang baik hanya (1), sedangkan pada kelas eksperimen (26) berada pada kategori sangat baik, (4) berada pada kategori cukup, dan untuk kategori Kurang baik (0). Hal ini menunjukan terdapat perbedaan frekuensi kreativitas siswa dalam menghasilkan photomapping antara kelas kontrol dengan kelas eksperimen. Gambar 1 menunjukkan perbandingan kreativitas siswa dalam merancang photomapping. 


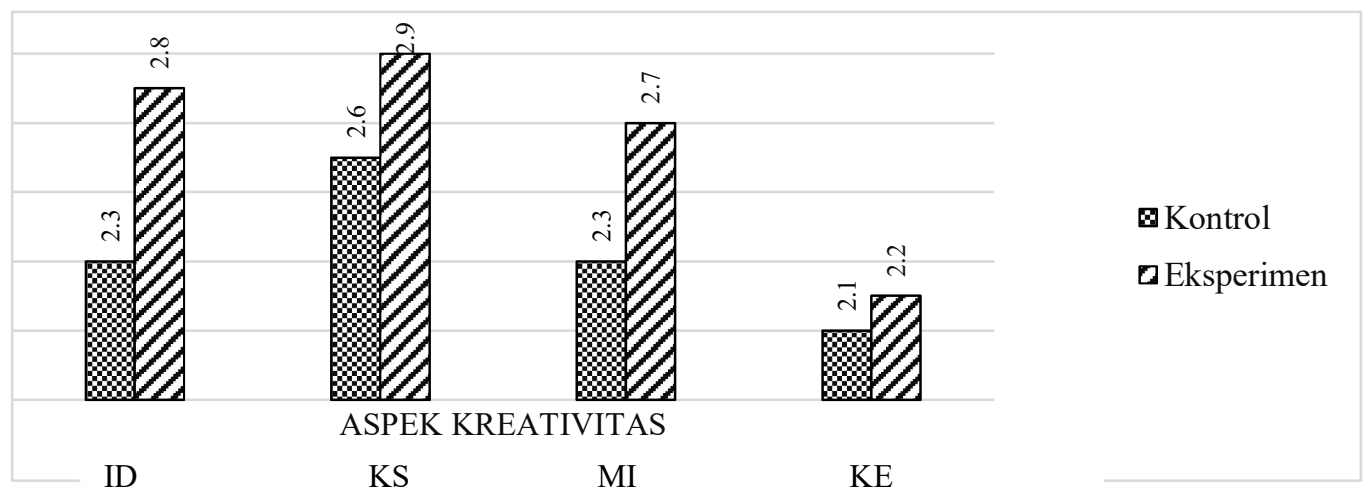

Gambar 1. Perbandingan Rata-Rata Skor Aspek-Aspek Kreativitas Peserta Didik Antara Kelas Kontrol Dengan Kelas Eksperimen

Ket: $\mathrm{ID}=$ ide; $\mathrm{KS}=$ Kontibusi siswa; $\mathrm{MI}=$ Menggabungkan ide; $\mathrm{KE}=$ Kemampuan

Dari ilustrasi Gambar 1 maka dapat diketahui jumlah rata - rata pada setiap aspek dari kelas eksperimen lebih tinggi dibandingan dengan kelas kontrol. Aspek yang memperoleh skor ratarata tertinggi pada kelas kontrol adalah KP $(2,6)$ dan skor yang terendah adalah $\operatorname{KE}(2,1)$. Sedangkan pada kelas eksperimen aspek yang memperoleh skor tertinggi adalah KP $(2,9)$ dan aspek yang memperoleh skor terendah adalah KE (2,2). Ditinjau dari aspek kreativitas, kelas eksperimen yang dibelajarkan dengan model Project Based Lerarning (PjBL) memperoleh skor lebih tinggi jika dibandingkan dengan kelas kontrol yang tidak menggunakan model PjBL.

Berdasarkan hasil uji Mann Whitney U Test dengan bantuan SPSS 17 for windows terhadap kreativitas siswa dalam menghasilkan photomapping menunjukan perbedaan yang nyata antara kelas kontrol dengan kelas eksperimen yang memperoleh taraf signifikansi sebesar $(\mathrm{Z}=-3,218, \alpha=0,05>\mathrm{p}=0,001)$. Untuk lebih jelas hasil analisis akan disajikan pada Tabel. 2

Tabel.2 Hasil Uji Mann Whitney U Test Terhadap Kreativitas Siswa Dalam Menghasilkan Photomapping Antara Kelas Eksperimen Dengan Kelas kontrol

\begin{tabular}{lc} 
& KREATIVITAS \\
\hline$Z$ & -3.218 \\
Asymp. Sig. (2-tailed) & .001 \\
\hline
\end{tabular}

Photomapping siswa berdasarkan enam aspek yang diamati, yaitu: 1) penggunaan media visual (MV); 2) desain warna dan garis (DWG); 3) kata kunci atau keterangan gambar (KK); 4) hubungan cabang utama dengan cabang yang lainnya (HC); 5) kelengkapan materi (KM); dan 6) Presentasi (P). Siswa secara berkelompok membuat photomapping dengan tema ekosistem, pada kelas kontrol maupun kelas eksperimen sama - sama menghasilkan enam photo mapping. Masing - masing kelompok dari kelas kontrol dan kelas eksperimen mengambil tema yang berbeda - beda yaitu ekosistem laut, ekosistem sungai, ekosistem hutan, ekosistem padang rumput, ekosistem sawah, dan ekosistem danau. Dari photomapping yang dihasilkan, menunjukan perbandingan photomapping kelas eksperimen lebih baik dibandingkan dengan kelas kontrol, hal itu dikarenakan dari segi aspek penilaian photomapping siswa kelas eksperimen lebih unggul, terutama pada aspek media visual (MV) dan desain warna dan gambar (DWG). Photomapping yang dirancang oleh siswa kelas kontrol dan kelas eksperimen secara 
visual memiliki perbedaan, yang diperkuat dengan uji statistik. Contoh photomapping yang dirancang oleh siswa dengan topik ekosistem dapat dilihat pada Gambar 2.

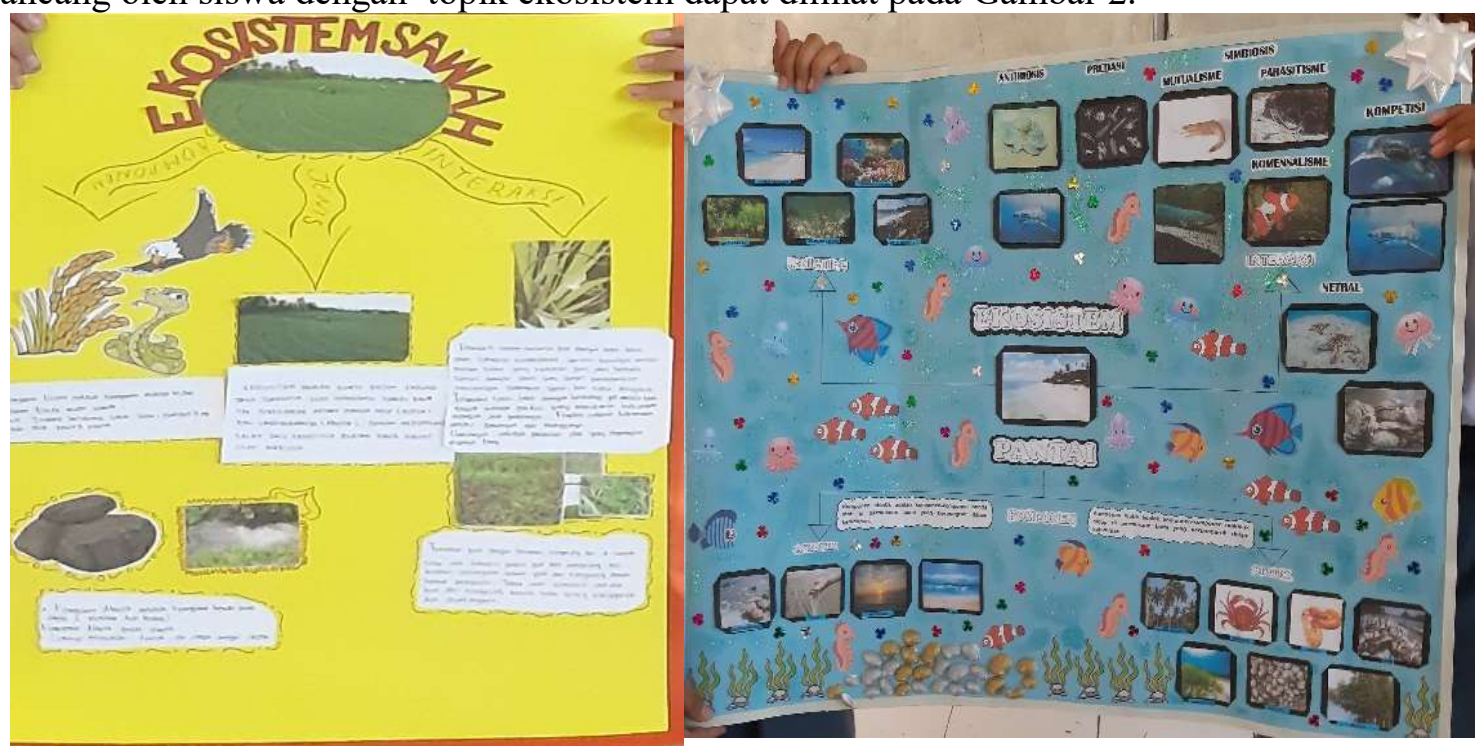

Gambar 2. Perbandingan photomapping siswa kelas kontrol (kiri) dengan kelas eksperimen (kanan)

Ditinjau dari hasil photomapping siswa , terdapat perbedaan distribusi frekuensi individu antara kelas kontrol dengan kelas eksperimen. Berdasarkan pada perbandingan frekuensi siswa kelas eksperimen dengan kelas kontrol akan disajikan pada Tabel 3

Tabel 3 Distribusi Frekuensi Individu Siswa Kelas Kontrol Dan Kelas Eksperimen

\begin{tabular}{|c|c|c|c|c|c|c|}
\hline \multirow[b]{2}{*}{ No } & \multirow[b]{2}{*}{ Kategori } & \multirow[b]{2}{*}{ Interval } & \multicolumn{4}{|c|}{ Individu } \\
\hline & & & $\begin{array}{c}\text { Kontrol } \\
(\mathrm{N}=30) \\
\mathrm{F}\end{array}$ & $(\%)$ & $\begin{array}{c}\text { Eksperimen } \\
(\mathrm{N}=30) \\
\mathrm{f}\end{array}$ & (\%) \\
\hline 1 & Tidak Baik & $6-10$ & 6 & 20,0 & 1 & 3,3 \\
\hline 2 & Kurang Baik & $11-15$ & 17 & 56,7 & 10 & 33,3 \\
\hline 3 & Baik & $16-19$ & 7 & 23,3 & 14 & 46,7 \\
\hline 4 & Sangat Baik & $20-24$ & 0 & 0,0 & 5 & 16,7 \\
\hline
\end{tabular}

Dapat dilihat pada Tabel 3 terdapat perbedaan antara frekuensi dan presentase antara kelas kontrol dan kelas eksperimen, dimana frekuensi dan presentase dari kelas kontrol lebih banyak siswa yang berada pada kategori kurang baik (17), selain itu pada kategori sangat baik frekuensi kelas kontrol adalah (0) dibandingkan dengan kelas eksperimen yang dominan berada pada aspek baik (14). Hal ini menunjukan adanya perbedaan hasil photomapping antara kelas eksperimen dengan kelas kontrol.

Ditinjau dari hasil distribusi masing - masing kelompok siswa antara kelas kontrol dengan kelas eksperimen terdapata perbedaan, dimana skor distribusi pada kelas eksperimen lebih tinggi dibandingkan pada kelas kontrol. perbandingan distribusi kelompok antara kelas eksperimen dengan kelas kontrol akan disajikan pada Tabel 4 
Tabel 4 Distribusi Frekuensi Kelompok Hasil Photomapping Kelas Kontrol Dan Kelas Eksperimen

\begin{tabular}{|c|c|c|c|c|c|c|}
\hline \multirow[b]{2}{*}{ No } & \multirow[b]{2}{*}{ Kategori } & \multirow[b]{2}{*}{ Interval } & \multicolumn{4}{|c|}{ Kelompok } \\
\hline & & & $\begin{array}{c}\text { Kontrol } \\
(\mathrm{N}=6) \\
\mathrm{F}\end{array}$ & $(\%)$ & $\begin{array}{c}\text { Eksperimen } \\
(\mathrm{N}=6) \\
\mathrm{f}\end{array}$ & $(\%)$ \\
\hline 1 & Tidak Baik & $6-10$ & 1 & 3,3 & 0 & 0,0 \\
\hline 2 & Kurang Baik & $11-15$ & 2 & 6,7 & 2 & 6,7 \\
\hline 3 & Baik & $16-19$ & 3 & 10,0 & 3 & 10,0 \\
\hline 4 & Sangat Baik & $20-24$ & 0 & 0,0 & 1 & 3,3 \\
\hline
\end{tabular}

Pada Tabel 4 menunjukan distribusi frekuensi pada masing - masing kelompok siswa antara kelas kontrol dengan kelas eksperimen berbeda, yaitu untuk kelas kontrol pada kategori baik mendapatkan (3), kategori Kurang baik (2), dan untuk kategori tidak baik hanya (1), sedangkan pada kelas eksperimen untuk kategori sangat baik hanya (1), kategori baik (3), dan kategori Kurang baik (2). Hal ini menunjukan adanya perbedaan hasil photomapping antara kelas eksperimen dengan kelas kontrol.

Ditinjau dari perbandingan rata-rata skor photomapping masing - masing kelompok, kelas eksperimen lebih tinggi dibandingkan kelompok kelas kontrol. Untuk lebih jelasnya akan disajikan pada Gambar 3.

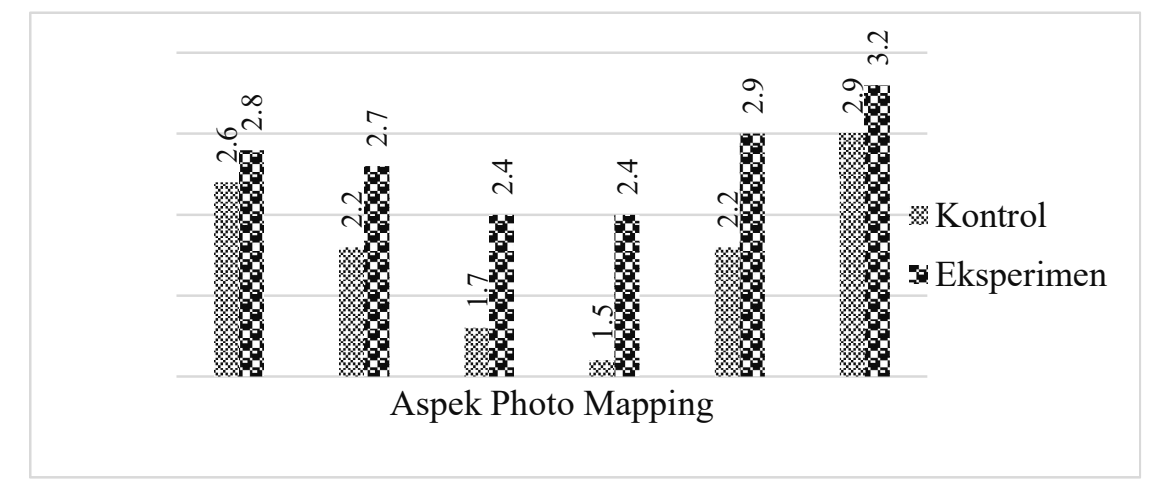

Gambar 3 Perbandingan Jumlah Skor Aspek Photomapping Siswa Pada Kelas Kontrol Dan Kelas Eksperimen

$\begin{array}{ll}\text { MV } & \text { : Media visual } \\ \text { DWG } & \text { : Desain warna dan garis } \\ \text { KK } & \text { : Kata kunci/keterangan } \\ & \text { gambar }\end{array}$

$\begin{array}{ll}\mathrm{HC} & \begin{array}{l}\text { : Hubungan cabang utama } \\ \text { dengan cabang yang lainnya }\end{array} \\ \mathrm{KM} & : \text { Kelengkapan materi } \\ \mathrm{PR} & \text { : Presentasi }\end{array}$

Dari hasil perbandingan Gambar 3 aspek yang memperoleh skor rata-rata tertinggi pada kelas eksperimen adalah aspek P $(3,2)$ dan skor terendah adalah aspek KK dan HC $(2,4)$, sedangkan pada kelas kontrol aspek yang memperoleh skor tertinggi adalah P $(2,9)$ dan skor terendah berada pada aspek HC $(1,5)$. 
Ditinjau dari perbandingan rata-rata skor photomapping masing - masing kelompok, kelas eksperimen lebih tinggi dibandingkan kelompok kelas kontrol. Pada kelas eksperimen kelompok C memperoleh skor tertinggi $(3,2)$ dan kelompok yang memperoleh skor terendah adalah kelompok E dan F (2,3). Sedangkan pada kelas kontrol kelompok yang mendapat skor tertinggi adalah kelompok D $(3,0)$ dan kelompok F yang memperoleh skor terndah $(1,5)$. Untuk lebih jelas perbandingan rata-rata skor photomapping masing - masing kelompok antara kelas eksperimen dengan kelas kontrol disajikan pada Gambar 4

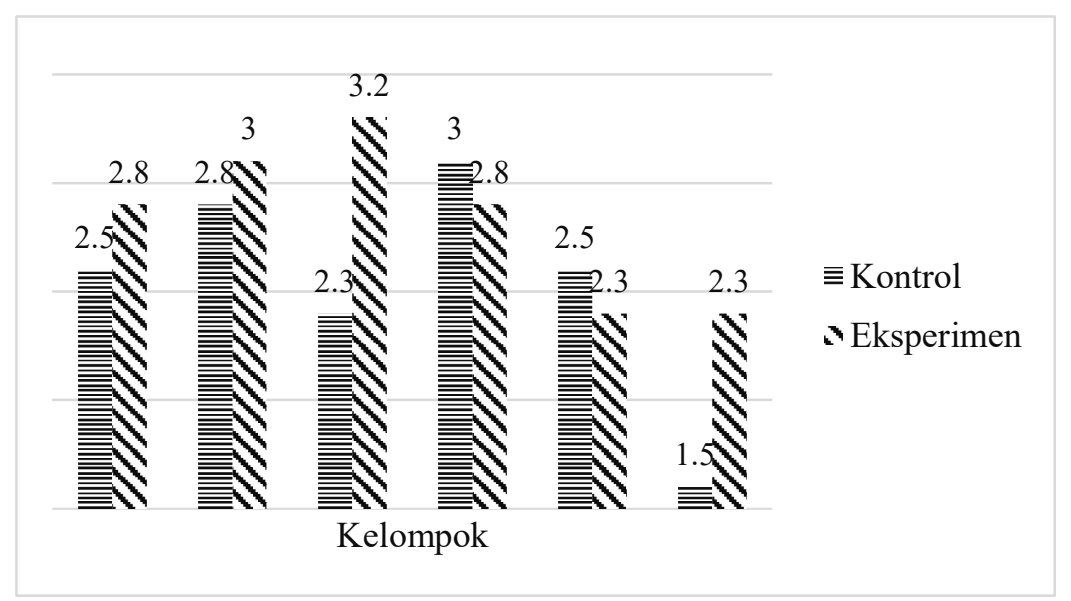

Gambar 4 Perbandingan Rata - Rata Skor Photomapping Masing - Masing Kelompok Pada Kelas Kontrol Dan Kelas Eksperimen

\section{Pembahasan}

Hasil skor keseluruhan kreativitas siswa dalam menghasilkan photomapping dan jumlah skor setiap aspek kelas eksperimen cenderung lebih tinggi dibandingkan dengan kelas kontrol. Begitu juga dengan distribusi frekuensi, dimana pada kelas eksperimen berada pada kategori sangat baik, dan cukup, sedangkan untuk kelas kontrol berada pada kategori sangat baik, cukup, dan Kurang baik.

Hal tersebut dapat diperkuat dari hasil analisis uji Mann Withney U Test yang menunjukkan adanya perbedaan nyata antara kreativitas siswa dengan photografi di kelas eksperimen yang menerapkan model pembelajaran $\mathrm{PjBL}$ dengan kelas kontrol yang menggunakan model konvensional atau ceramah, dengan taraf signifikansi $(\alpha=0,05>p=0,001)$. Hal tersebut disebabkan karena kelas eksperimen yang menerapkan model Project Based Learning (PjBL) mengarahkan dan menjelaskan kepada siswa bagaimana proses pembuatan projek yang baik, terutama dalam pembuatan photomapping. Hasil penelitian ini mendukung hasil penelitian (Puspawati et al., 2016) yang menyatakan bahwa kegiatan pembelajaran yang memanfaatkan kearifan lokal subak (etnosains) yang dipadukan dengan sains modern (kamera) yang tertuang dalam kolaborasi fotografi berpartisipasi telah mampu meningkatkan minat belajar biologi. (Suryanti, 2015) menyatakan bahwa implementasi model PjBL dengan media mind mapping tiga dimensi dapat mempengaruhi kreativitas siswa , Hal yang sama juga ditunjukan oleh penelitian (Titu, 2015) yang menyatakan bahwa penerapan pembelajaran 
Project Based Learning sangat mendukung kreativitas siswa. Hal ini membuktikan bahwa dengan menerapkan model pembelajaran yang inovatif dapat memaksimalkan kreativitas siswa.

Berdasarkan hasil uji Mann Withney U Test kreativitas siswa dalam menghasilkan photomapping, dari masing - masing aspek antara kelas kontrol dengan kelas eksperimen terdapat tiga aspek yang memiliki perbedaan yang nyata dengan aspek lainnya, yaitu pada aspek Ide (ID) dengan taraf signifikasi $p=0,001$. Kontribusi Siswa (KP) dengan taraf signifikansi $\mathrm{p}=0,011$ dan Menggabungkan Ide (MI) dengan taraf signifikansi $\mathrm{p}=0,035$. Hal ini karena dengan adanya kegiatan projek yang menantang yang memberikan kebebasan pada siswa untuk membidikan kameranya dalam membuat photomapping akan membuat proses pembelajaran menjadi menyenangkan. Hal ini sejalan dengan penelitian (Puspawati et al., 2016) yang menyatakan bahwa pembelajaran kolaborasi fotografi berpartisipasi (KFB) dapat menganalisis pengetahuan konseptual siswa karena siswa dikondisikan belajar pada suasana yang menyenangkan sehingga proses transfer berlangsung dengan mudah. Kegiatan photografi dalam pembelajaran membuats siswa senang dan antusias dalam belajar. Hasil penelitian (Puspawati \& Surata, 2018) menunjukkan bahwa pembelajaran berbantuan photovoice dan digital stories merupakan kegiatan bermakna dan menyenangkan dan memberikan kesempatan kepada siswa bekerja secara berkelompok, melatih siswa dalam mengemukakan pendapat dan ide melalui foto dan video serta memotivasi siswa untuk lebih peduli terhadap lingkungan. Pada aspek Kemampuan Elaborasi (KE) taraf signifikansinya adalah $\mathrm{p}=0,899$, hal ini dinyatakan bahwa tidak terdapat perbedaan nyata kemampuan elaborasi antara kelas eksperimen dengan kelas kontrol, karena siswa kurang mengerjakan proyek secara tekun, cermat, dan saat siswa diberikan masukan tidak didengar dengan baik, selain itu juga observer belum maksimal dalam menilai kemampuan elaborari siswa karena kurangnya waktu, sehingga memperoleh skor yang rendah. Skor rata - rata keseluruhan hasil photomapping siswa dan jumlah setiap aspek dikelas eksperimen cenderung lebih tinggi. Begitu juga dengan distribusi frekuensi, dimana pada kelas eksperimen berada pada kategori sangat baik, baik, dan KB, sedangkan pada kelas kontrol berada pada kategori baik, KB, dan tidak baik, hal tersebut dapat diperkuat dari hasil analisis uji Mann Withney U Test yaitu taraf signifikansinya adalah $(\alpha=0,05>p=0,000)$ sehingga terdapat perbedaan nyata antara kelas kontrol dengan kelas eksperimen.

Perbedaan hasil hasil photomapping tersebut disebabkan karena pada kelas eksperimen menerapkan metode pembelajaran Project Based Learning yang memberikan kesempatan siswa untuk melakukan investigasi mendalam secara berkelompok tentang suatu masalah dan menemukan solusi dengan pembuatan proyek berupa photo mapping. Projek Based Learning adalah model pembelajaran yang menggunakan proyek/kegiatan sebagai media, siswa melakukan eksplorasi, penilaian, interpretasi, sintesis, dan informasi untuk menghasilkan berbagai bentuk hasil belajar (Ainamulyana, 2018). Hal ini sejalan dengan penelitian sebelumnya tentang pengruh pembelajaran inovatif terhadap hasil photomapping siswa dari (Suandewi, 2015), menyatakan bahwa penerapan media photomapping berpengaruh sangat nyata terhadap hasil photomapping siswa. Hal tersebut didukung dengan penelitian (Sari \& Susilo, 2016), yang menyatakan mind map dapat digunakan untuk melatih mahasiswa dalam berpikir kreatif sehingga memunculkan kreativitas dalam membuat mind mapping.

Berdasarkan hasil uji Mann Withney U Test hasil photomapping siswa antara kelas kontrol dengan eksperimen, dari keenam aspek tersebut terdapat empar aspek yang memiliki perbedaan yang nyata dan dua aspek yang tidak berbeda nyata. Dimana untuk aspek yang berbeda nyata 
adalah aspek Desai Warna \& Gambar (DWG) dengan taraf signifikasi $\mathrm{p}=0,008$, Kata Kunci (KK), Hubungan Cabang (HC) dan Kelengkapan Materi (KM) memiliki taraf signifikansi yang sama yaitu $\mathrm{p}=0,000$. Sedangkan untuk aspek yang tidak berbeda nyata adalah aspek Media Visual (MV) dengan taraf signifikansinya $\mathrm{p}=0,299$ dan aspek Presentasi (PR) yang memiliki taraf signifikansi $\mathrm{p}=0,108$. Hal ini disebakan karena pada aspek media visual yang digunakan siswa dalam photomapping antara kelas kontrol dengan kelas eksperimen, untuk beberapa kelompok telah menggunakan photo dengan baik, gambar cukup jelas, serta sesuai dengan tema yang dipilih, sedangkan tidak berbeda nyata pada aspek presentasi dikarenakan perserta didik baik dari kelas kontrol maupun kelas eksperimen sudah terbiasa melakukan presentasi dikelas, sehingga siswa percaya diri dan memaparkan dengan baik hasil photomapping yang telah dibuat. Hal ini sejalan dengan penelitian (Jaya et al., 2019) yang menyatakan bahwa penerapan Model Problem Based Learning pada materi SPLTV dapat meningkatkan rasa percaya diri dan kemampuan komunikasi matematis siswa kelas X MIPA 8 SMA Negeri 4 Semarang tahun pelajaran 2018/2019.

Temuan yang diperoleh selama penelitian antara lain : 1) kontribusi siswa pada kelas kontrol dengan kelas eksperimen sama - sama memiliki skor tertinggi, hal ini dikarenakan siswa cukup aktif dan antusias dalam mengerjakan proyek berupa photomapping, pembagian tugas dalam pembuatan proyekpun tertata dengan baik, sehingga siswa sangat berkontribusi dalam mengerjakan proyek untuk menuangkan kreativitas mereka. 2) kemampuan elaborasi siswa sangat kurang, karena siswa kurang tekun dan cermat dalam mengerjakan proyek yang ditugaskan dan kurangnya waktu dalam menilai kemampuan elaborasi siswa. 3) kemampuan siswa dalam menggabungkan ide masih kurang karena masih mementingkan egonya masing masing, sehingga membutuhkan waktu yang cukup lama dalam mendapatkan kesepakatan yang sama. Dari temuan tersebut, dibutuhkan waktu penelitian yang lebih lama agar mendapat hasil yang maksimal, sehingga pada penilaian aspek kemampuan elaborasi bisa dinilai dengan baik. Sehingga dapat disimpulkan bahwa penerapan photografi dengan model $\mathrm{PjBL}$ dapat mengasah kreativitas siswa dalam merancang photomapping.

\section{Kesimpulan}

Dari hasil penelitian tersebut dapat disimpulkan bahwa penerapan photografi dengan model $\mathrm{PjBL}$ dapat mengasah kreativitas siswa dalam merancang photomapping $(\mathrm{z}=-3,218$, $\mathrm{p}=0,001)$.

\section{Ucapan Terima Kasih}

Ucapan terimakasih penulis sampaikan kepada Kepala Sekolah, guru mata pelajaran Biologi, dan siswa kelas X IPA 9, X IPA 5 SMAN 2 Denpasar, yang telah memberikan ijin untuk melakukan penelitian, membina dan membimbing penulis selama melakukan penelitian sehingga tulisan ini dapat diselesaikan. Dan juga rekan sejawat yang telah membantu sebagai observer.

\section{Referensi}

Agustina, V. (2013). Penerapan mind mapping dalam pembelajaran IPA pada materi daur air untuk meningkatkan kreativitas. [PDF Dokumen]. Diunduh dari: http://repository.upi.edu/1742/6/S PGSD 0904085 chapter3.pdf. Pada tanggal 15 Februari 2019 
Ainamulyana. (2018). Pembelajaran berbasis proyek (Prodect Based Learning). Diunduh dari: https://ainamulyana.blogspot.com/2016/06/model-pembelajaran-berbasis-proyek.html. Pada tanggal 10 Maret 2019

Ismanto, I. (2018). Fotografi Sebagai Media Monitoring Urban Farming Berbasis Pendokumentasian Dan Partisipasi Anak Dalam Menciptakan Lingkungan Ramah Anak Di Wilayah Pegirian Surabaya. spectā: Journal of Photography, Arts, and Media, 2(2), 8190 .

Jagantara, I.M.W. (2014). Pengaruh model pembelajaran berbasis proyek (project based learning) terhadap hasil belajar biologi ditinjau dari gaya belajar siswa sma. [PDF Dokumen]. Diunduh dari: https://media.neliti.com/media/publications/122778-IDpengaruh-model-pembelajaran-berbasis-pro.pdf. Pada tanggal 26 Mei 2019

Jaya, A., Waluyo, S. B., \& Siswanto, B. (2019). Implementasi Model Problem Based Learning untuk Meningkatkan Kemampuan Komunikasi Matematis dan Percaya Diri Siswa Kelas X Sma Negeri 4 Semarang. PRISMA, Prosiding Seminar Nasional Matematika, 2, 410 415.

Puspawati, D. A., \& Surata, S. P. K. (2018). EKOPEDAGOGI BERBASIS LANSKAP BUDAYA SUBAK: SUMBER BELAJAR ALTERNATIF DALAM MENUNJANG EKOWISATA DAN PENGELOLAAN LINGKUNGAN. Prosiding Seminar Nasional Pendidikan Biologi ( ISBN : 978-602-61265-2-8), Juni 2018, 858-863.

Puspawati, D. A., Surata, S. P. K., \& Ekayanti, N. W. (2016). Peningkatan kompetensi dasar belajar melalui pembelajaran kolaborasi fotografi berpartisipasi. Prosiding Seminar Nasional Hasil Penelitian, 11, 112-120.

Sari, F. N., \& Susilo, H. (2016). PENGGUNAAN PETA PIKIRA ( MIND MAPPING ) SEBAGAI INSTRUMEN PENILAIAN KREATIVITAS MAHASISWA CALON GURU BIOLOGI PADA. Prosiding SNPBS (Seminar Nasional Pendidikan Biologi Dan Saintek) $\mathrm{Ke}-1,666-674$.

Suandewi, N.LA.A. (2015). Pengaruh Model Pembelajaran Picture and Picture Menggunakan Media Photomapping Untuk Menganalisis Keterampilan Proses Sains Siswa Kelas VII SMPN 2 Denpasar. (skripsi tidak dipublikasikan). FKIP Uneversitas Mahasaraswati Denpasar, Denpasar.

Suryanti, N.HW. (2015). Implementasi Model Pembelajaran Project Based Learning (PjBL) Dengan Media Mind Mapping 3 Dimensi Terhadap Kreativitas Siswa Dan Kemampuan Berfikir Kritis Siswa SMA Negeri 7 Denpasar. (skripsi tidak dipublikasikan). FKIP Uneversitas Mahasaraswati Denpasar, Denpasar.

Titu, M. A. (2015). PENERAPANMODEL PEMBELAJARAN PROJECT BASED LEARNING (PjBL) UNTUKMENINGKATKAN KREATIVITAS SISWA PADA MATERI KONSEPMASALAH EKONOMI. Prosiding Seminar Nasional, 176-186. 